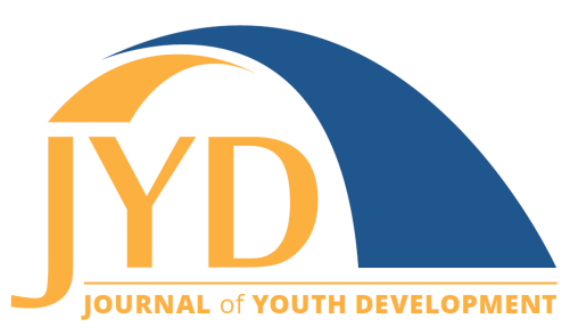

http://jyd. pitt. edu/ | Vol. 13 Issue 3 DOI 10.5195/jyd.2018.663 | ISSN 2325-4017 (online)

\title{
WAVE Project: Sport Nutrition Education Resources
}

\section{Siew Sun Wong}

Oregon State University

siewsun.wong@oregonstate.edu

Melinda M. Manore

Oregon State University

melinda.manore@oregonstate.edu

\section{Kari Pilolla}

California Polytechnic State University

kpilolla@calpoly.edu

\section{Ingrid Skoog}

Oregon State University

ingrid.skoog@oregonstate.edu

\section{Darcie Hill}

Western Washington University

darcie.hill@wwu.edu

\section{Taryn Hand}

University of Oregon

tarynmhand@gmail.com

\begin{abstract}
The WAVE Ripples for Change: Obesity Prevention in Active Youth (WAVE) project's primary objective is to prevent unhealthy weight gain among high school athletes through healthy eating and reduced sedentary time. Educators are familiar with the myriad of challenges in presenting nutrition, diet, and physical activity information to high school students. WAVE uses adolescent athletes' interest in sport to draw them into the topic of sport nutrition and healthy eating; helping them apply the knowledge and skills they learned in class, on the field, and in their lives. WAVE developed and field-tested an after-
\end{abstract}

(cc) EY New articles in this journal are licensed under a Creative Commons Attribution 4.0 License. This journal is published by the University Library System, University of Pittsburgh and is cosponsored by the University of Pittsburgh Press. The Journal of Youth Development is the official peer-reviewed publication of the National Association of Extension 4-H Agents and the National AfterSchool Association. 
Sport Nutrition Education Resources

school program for high school athletes that includes 7 sport nutrition lessons (30 to 45 minutes each) and 3 team-building, family and consumer sciences life-skill workshops. WAVE also developed a cloudbased data management system to support the tracking of learner profiles, survey administration, big data visualization, and automated health report generation.

Key words: sport nutrition, adolescent athletes, active youth, experiential learning, youth development

\section{Background}

The WAVE Ripples for Change: Obesity Prevention in Active Youth (WAVE) is a 5-year integrated research, education, and Extension project funded by the National Institute of Food and Agriculture's Agriculture and Food Research Initiative. WAVE developed and field-tested educational materials with 488 multiethnic high school (HS) soccer players (14 to 19 years old). WAVE capitalized on adolescents' interest in sport to teach sport nutrition education to improve eating behaviors for sport performance, health, and obesity prevention. Athletes already know about physical activity (PA), training hard, and working toward a goal. WAVE capitalized on this interest and passion for sport by developing a program to encourage lifelong healthy eating and PA, thus, prevent unwanted weight gain as they transition to adulthood.

\section{Educational Materials}

The following WAVE resources complement each other but they can be delivered independently.

\section{WAVE Sport Nutrition Curriculum}

This evidence-based curriculum aims to improve eating behaviors for sport performance, weight management, and health (Manore, Meyer, \& Thompson, 2009; Meyer, Manore, \& Berning, 2012; Thomas, Erdman, \& Burke, 2016). Included in the curriculum are the 2018 Physical Activity Guidelines Advisory Committee Sceintific Report (U.S. Department of Health and Human Services, 2018); position statements on sport nutrition, energy needs for sport (Thomas et al., 2017; Mountjoy et al., 2018), and sport nutrition for adolescent athletes (Desbrow et al., 2014); and information on hydration (Sawka et al., 2007) and exertional heat illnesses (Amstrong et al., 2007; Casa et al., 2015). The curriculum also incorporates best practices from key existing sport nutrition curricula (CATCH Global Foundation, 2014; Houtkooper, Abbot, \& Mullins, 2007; National Dairy Council, 2017). 


\section{Sport Nutrition Education Resources}

In pilot testing (2014-15), 30 high school soccer players (ages 14 to 19 years old) and coaches received all seven lessons face-to-face from registered dietitian nutritionists (RDNs) trained in sport nutrition (Certified Specialists in Sport Dietetics/CSSD), college athletes, or nutrition and exercise science educators. The curriculum was revised based on learner and educators' input. In the WAVE intervention, the curriculum was delivered over a 2-year period (2015-17) to teams of multiethnic soccer players ( $n=488$, ages 14-19) attending high school in Oregon and their coaches by a RDN trained in sport nutrition and experienced in collegiate or professional soccer. Post-intervention, two external reviewers blind-reviewed the curriculum.

\section{Target Audience}

The target audience is active youth. Although field-tested in high school soccer players, the curriculum is adaptable to address adolescents involved in many different sports and activities.

\section{Educators}

Knowledgeable nutrition or health professionals trained in sport nutrition can deliver the curriculum to active youth. These educators could be Extension Family and Consumer Sciences (FCS)/4-H faculty, high school health teachers, or RDNs.

\section{Program Delivery}

While we delivered the curriculum over the fall soccer season at high schools and during summer camps at the university campus, the delivery setting is flexible, including classroom, after-school, weekend/summer workshops or camps.

\section{Content Highlights}

The curriculum consists of seven lessons each lasting 30 to 45 minutes. The lesson duration can be flexible, depending on the number of activities the educator includes, and when and where the lessons are delivered. We found that coaches are reluctant to take practice time away for sport nutrition lessons; thus, we needed short, focused, and student-engaged lessons. Coach involvement with the lessons and reinforcement of the messages in practice are critical to engaging the athletes and changing behaviors. Table 1 lists the topics included in the curriculum, each based on the latest sport nutrition research, with reference sources provided in every lesson plan. 


\section{Sport Nutrition Education Resources}

Each lesson contains the following items:

- Lesson plan, including in-class activities, supplies checklist, and specific references for additional information on the topic

- PowerPoint slides with presenter notes; unlocked for educators to customize the lesson for their audience

- Activities (such as clickers and recipe tasting) and worksheets to engage students

- Handouts for coaches or athletes

Table 1. WAVE Sport Nutrition Curriculum Description

\begin{tabular}{|c|c|}
\hline Lesson titles & Lesson goals \\
\hline $\begin{array}{l}\text { Lesson 1: } \\
\text { Hydration }\end{array}$ & $\begin{array}{l}\text { To provide athletes with the knowledge to understand the purpose of proper } \\
\text { hydration for sport and exercise, and give them the tools and skills needed to } \\
\text { implement a hydration plan to achieve the following: } \\
\text { - delay onset of dehydration, } \\
\text { - improve and maintain training and performance, and } \\
\text { - decrease risk of illness and injury related to dehydration. }\end{array}$ \\
\hline $\begin{array}{l}\text { Lesson 2: Pre- } \\
\text { Exercise } \\
\text { Fueling }\end{array}$ & $\begin{array}{l}\text { To provide athletes with the knowledge necessary to understand the purpose of } \\
\text { proper fueling prior to exercise, and give them the tools and skills necessary to } \\
\text { implement a pre-exercise fueling plan to achieve the following: } \\
\text { - delay onset of fatigue and dehydration by "topping off" fueling and hydration } \\
\text { levels in the body, } \\
\text { - improve and maintain training and performance, and } \\
\text { - avoid GI (gastrointestinal) discomfort. }\end{array}$ \\
\hline $\begin{array}{l}\text { Lesson 3: } \\
\text { During } \\
\text { Exercise } \\
\text { Fueling }\end{array}$ & $\begin{array}{l}\text { To provide athletes with the knowledge to understand the purpose of proper fueling } \\
\text { during exercise, and give them the tools and skills necessary to implement a during- } \\
\text { exercise fueling plan to achieve the following: } \\
\text { - provide fuel to maintain blood glucose levels; } \\
\text { - delay onset of symptoms related to glycogen depletion, low blood glucose, } \\
\text { and dehydration; } \\
\text { - improve and maintain training and performance; and } \\
\text { - avoid GI discomfort. }\end{array}$ \\
\hline
\end{tabular}


Table 1 (continued).

\begin{tabular}{|c|c|}
\hline Lesson titles & Lesson $\mathrm{g}$ \\
\hline $\begin{array}{l}\text { Lesson 4: } \\
\text { Recovery } \\
\text { Nutrition }\end{array}$ & $\begin{array}{l}\text { To provide athletes with the knowledge to understand the purpose of proper recovery } \\
\text { nutrition and the skills to implement a recovery nutrition plan to achieve the } \\
\text { following: } \\
\text { - replenish glycogen stores; } \\
\text { - } \quad \text { rehydrate; } \\
\text { initiate recovery and adaptation processes in the body that require } \\
\text { carbohydrate, protein, and water; and } \\
\text { achieve the maximum gains from training to maintain and/or improve } \\
\text { performance. }\end{array}$ \\
\hline $\begin{array}{l}\text { Lesson 5: } \\
\text { Body } \\
\text { Composition } \\
\text { and Body } \\
\text { Image }\end{array}$ & $\begin{array}{l}\text { (Lessons are different for males and females.) } \\
\text { Male: To provide athletes with an understanding of body composition, how it is } \\
\text { measured, and factors that influence body size and composition. } \\
\text { Female: To provide athletes with an understanding of body composition and a heathy } \\
\text { perspective on body image in order to develop body appreciation and acceptance. }\end{array}$ \\
\hline $\begin{array}{l}\text { Lesson 6: } \\
\text { Maintaining } \\
\text { Muscle and } \\
\text { Staying Well }\end{array}$ & $\begin{array}{l}\text { To provide athletes with the knowledge to understand how nutrient timing and } \\
\text { composition of foods/meals will help them meet their protein needs. } \\
\text { To help athletes understand the importance of diet and lifestyle habits that will help } \\
\text { them maintain a strong immune system and stay healthy while participating in sports. }\end{array}$ \\
\hline $\begin{array}{l}\text { Lesson 7: } \\
\text { Eating Well } \\
\text { while Eating } \\
\text { Out }\end{array}$ & $\begin{array}{l}\text { To help athletes understand how to make better food selections outside the home } \\
\text { that are within their budgets. Raise awareness that cooking and eating food from } \\
\text { home can be the most affordable and 'healthy' option. }\end{array}$ \\
\hline
\end{tabular}

\section{Team-Building Workshops}

The curriculum contains three 60- to 90-minute team-building workshops (TBWs) that cover the following topics: (1) Grocery Store Scavenger Hunt (grocery shopping/meal planning); (2) Let's Cook (meal preparation); and (3) Harvesting and Gardening (gardening techniques). Each TBW comes with a lesson plan, competition, knowledge and skill assessments, handouts, and signage (Table 2). 
Sport Nutrition Education Resources

Table 2. WAVE Team-Building Workshops to Teach FCS Skills

\begin{tabular}{|c|c|c|c|}
\hline TBW & 1. Scavenger Hunt & 2. Let's Cook & $\begin{array}{l}\text { 3. Harvesting \& } \\
\text { Gardening }\end{array}$ \\
\hline FCS Skills & $\begin{array}{l}\text { Grocery shopping and } \\
\text { meal planning }\end{array}$ & Meal preparation & Gardening techniques \\
\hline $\begin{array}{l}\text { Learning } \\
\text { objectives }\end{array}$ & $\begin{array}{l}\text { - Plan a lunch menu for } \\
\text { two high school } \\
\text { athletes or other } \\
\text { youth group/club. } \\
\text { Grocery shop within a } \\
\$ 10 \text { budget to select } \\
\text { the most nutritious } \\
\text { ingredients. } \\
\text { Understand how to } \\
\text { compare prices by } \\
\text { using the unit price. } \\
\text { Read the nutrition } \\
\text { facts label to make } \\
\text { better food choices. }\end{array}$ & $\begin{array}{l}\text { Understand the } \\
\text { health benefits of } \\
\text { vegetable } \\
\text { consumption. } \\
\text { Increase exposure to } \\
\text { unfamiliar } \\
\text { vegetables. } \\
\text { Learn basic kitchen } \\
\text { safety and cooking } \\
\text { techniques. } \\
\text { Work in teams to } \\
\text { prepare a pasta } \\
\text { ratatouille recipe. }\end{array}$ & $\begin{array}{l}\text { Describe physical } \\
\text { characteristics of three } \\
\text { different plant families. } \\
\text { - Identify and harvest } \\
\text { ripe produce. } \\
\text { - Describe the culinary } \\
\text { characteristics of three } \\
\text { crops from different } \\
\text { plant families. } \\
\text { With a team, create a } \\
\text { recipe using the } \\
\text { 'produce of the day' } \\
\text { from a farm. }\end{array}$ \\
\hline $\begin{array}{l}\text { Workshop } \\
\text { duration }\end{array}$ & $60-90$ minutes & 60 minutes & 60 minutes \\
\hline Location & $\begin{array}{l}\text { Grocery store nearest to } \\
\text { school }\end{array}$ & $\begin{array}{l}\text { School kitchen, } \\
\text { classroom, cafeteria, or } \\
\text { outdoor }\end{array}$ & $\begin{array}{l}\text { School garden, nearest } \\
\text { community or faith-based } \\
\text { garden }\end{array}$ \\
\hline Lesson materials & $\begin{array}{l}\text { Lesson plan - adapted } \\
\text { with permission from } \\
\text { Cooking Matters At } \\
\text { The Store } \\
\text { Scavenger hunt map } \\
\text { with tips } \\
\text { Scoring sheet } \\
\text { A written survey ( } 2 \\
\text { questions) }\end{array}$ & 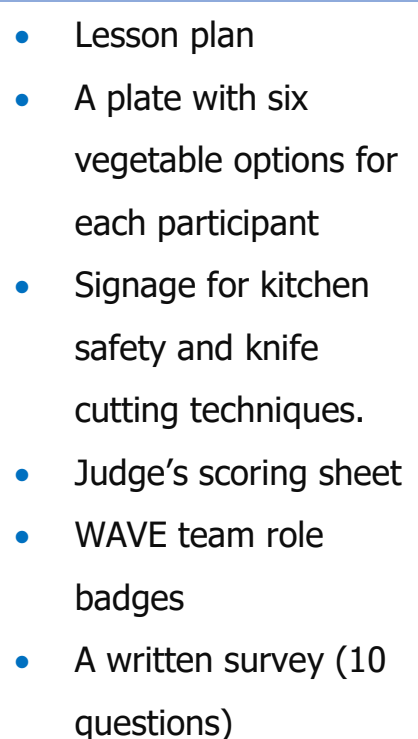 & $\begin{array}{l}\text { Lesson plan developed } \\
\text { by Youth Farm } \\
\text { manager } \\
\text { - Ingredient list for food } \\
\text { tasting } \\
\text { Knowledge assessment } \\
\text { tool (dots and large } \\
\text { post-it note) } \\
\text { Farm-fresh produce to } \\
\text { take home for free }\end{array}$ \\
\hline
\end{tabular}


Table 2 (continued).

\begin{tabular}{|l|l|l|l|}
\hline TBW & 1. Scavenger Hunt & 2. Let's Cook & $\begin{array}{l}\text { 3. Harvesting \& } \\
\text { Gardening }\end{array}$ \\
\hline $\begin{array}{l}\text { Suggested } \\
\text { reward }\end{array}$ & $\begin{array}{l}\$ 10 \text { grocery store gift card } \\
\text { for each youth or } \$ 15 \\
\text { grocery store gift card for } \\
\text { each winner }\end{array}$ & $\begin{array}{l}\text { \$5 Jamba Juice gift card } \\
\text { for each youth }\end{array}$ & $\begin{array}{l}\text { Optional "produce of the } \\
\text { week" for each youth to } \\
\text { take home. }\end{array}$ \\
\hline
\end{tabular}

\section{Educators}

Knowledgeable professionals in gardening and cooking, such as Extension FCS/Master Gardener/4-H instructors, 4-H camp ambassadors, health teachers or RDNs, can deliver the workshops.

\section{Program Delivery}

Each workshop is independent. Delivery may be most feasible at/near school during afterschool/weekend/summer/camps. To engage student-friendly competitions, each workshop provided gift card rewards.

\section{WavePipe and OrangeWave}

WavePipe is a cloud-based data management system hosted by Oregon State University for teaching/research professionals to store and manage participant data, communicate via texts/emails with specific groups, and schedule and administer online surveys. To manage measured PA, WavePipe automatically downloads and backs up Fitbit data daily and automates customized reports (e.g., health reports to compare participant's steps/day to their peers' average and national recommendations). WavePipe evolved into OrangeWave, which contains the most robust and popular features of WavePipe, with improved user interface, and is specifically designed to be more customizable by the user.

\section{Accessing WAVE Resources}

The WAVE Sport Nutrition Curriculum is available free of charge at https://catalog.extension.oregonstate.edu/em9218. The Team-Building Workshops Curriculum is also free and will be available at https://extension.oregonstate.edu/families- 
Journal of Youth Development | http://jyd.pitt.edu/ | Vol. 13 Issue 3 DOI 10.5195/jyd.2018.663

Sport Nutrition Education Resources

health/nutrition/waveripples-change-obesity-prevention-active-youth later in 2018. OrangeWave subscription is fee-based by request at the WAVE resource website.

\section{Conclusion}

The benefits of WAVE project resources make it worthy of consideration by health and youth development professionals because this is the first sport nutrition curriculum aimed at active youth in the United States. Professionals who take advantage of these resources will not only find them easy and practical to use; they can also feel more confident in knowing that all materials are research-based, and designed to address active youth developmental needs.

\section{References}

Armstrong, L. E., Casa, D. J., Millard-Stafford, M., Moran, D. S., Pyne, S., \& Roberts, W. (2007). Exertional heat illness during training and competition. Medicine and Science in Sports and Exercise, 39, 556-572. doi: 10.1249/MSS.0b013e31802fa199

Casa, D. J., DeMartini, J. K., Bergeron, M. F., Csillan, D., Eichner, E. R. Lopez, R. M., . . Yeargin, S. W. (2015). National Athletic Trainers' Association position statement: Exertional heat illnesses. Journal of Athletic Training, 50(9), 986-1000. doi: 10.4085/1062-6050-50.9.07

CATCH Global Foundation. (2014). Coordinated approach to child health. Retrieved from https://catchinfo.org/

Desbrow, B., McCormack, J., Burke, L. M., Cox, G. R., Fallon, K., Hislop M., . . . Leveritt, M. (2014). Sports Dietitians Australia position statement: Sports nutrition for the adolescent athlete. International Journal of Sport Nutrition and Exercise Metabolism, 24, 570-584. Retrieved from http://journals.humankinetics.com/doi/abs/10.1123/ijsnem.2014-0031

Houtkooper, L., Abbot, J. M., \& Mullins, V. (2007). Winning sports nutrition. Tucson, AZ: DSW Fitness. Manore, M. M., Meyer, N. L., \& Thompson, J. (2009). Sport nutrition for health and performance ( $2^{\text {nd }}$ ed.). Champaign, IL: Human Kinetics.

Meyer, N. L., Manore, M. M., \& Berning, J. (2012). Fueling for fitness: Food and fluid recommendations for before, during and after exercise. American College of Sports Medicine's Health \& Fitness Journal, 16(3), 7-12. doi: 10.1249/01.FIT.0000414750.69007.fC

Mountjoy, M., Sundgot-Borgen, J., Burke, L., Ackerman, K., Blauwet, C., Constantini N., . . Budgett, R. (2018). International Olympic Committee (IOC) consensus statement on relative energy deficiency in sport (RED-S): 2018 Update. International Journal of Sport Nutrition and Exercise Metabolism, 1-19. doi: 10.1123/ijsnem.2018-0136

National Dairy Council. (2017). Fuel up to Play 60. Retrieved from https://www.fueluptoplay60.com/ 
Sawka, M. N., Burke, L. M., Eichner, E. R., Maughan, R. J., Montain, S. J., \& Stachenfeld, N. S. (2007). American College of Sports Medicine position stand. Exercise and fluid replacement. Medicine and Science in Sports and Exercise, 39, 377-390. doi: 10.1097/00005768-199610000-00045

Thomas, D. T., Erdman, K. A., \& Burke, L. M. (2016). American College of Sports Medicine, Academy of Nutrition and Dietetics, Dietitians of Canada joint position statement: Nutrition and athletic performance. Medicine and Science in Sports and Exercise, 48(3), 543-568. doi: 10.1249/MSS.0000000000000852

U.S. Department of Health and Human Services. (2018). 2018 Physical Activity Guidelines Advisory Committee scientific report. Retrieved from: https://health.gov/paguidelines/secondedition/report/pdf/PAG_Advisory_Committee_Report.pdf 